\title{
PENGARUH INFLASI, SUKU BUNGA DAN NILAI TUKAR RUPIAH \\ TERHADAP HARGA SSAHAM PERUSAHAAN SEKTOR PROPERTI DAN REAL ESTATE YANG TERCATAT DI BURSA EFEK INDONESIA
}

\author{
Fitri Ramadani \\ Department of Management FEB UMM
}

\begin{abstract}
Thepurpose of this research is to knowthe influence of inflation,interestrates, and the exchange rate of the rupiah against the stock price. This research wasconducted on 30 companies secto rproperty and real estatelisted onthe IndonesiastockexchangePeriod 2012 - 2014. Data analysis techniques used in research namely OLS (Ordinary Least Square)through the help of multiple software SPSS version 18.0. Research results indicate that simultaneous inflation, interest rates, the rupiah exchanger ateand effect on stock prices. Research partially indicate that inflation is not a negative and apositive effect against the stock price, while the negative effect of interest rates significantly to the stock price and the exchange rate of rupiah apositive significant effect against the stock price.
\end{abstract}

Key words: inflation, interest rates, exchange rate of the Rupiah, stock prices

\section{PENDAHULUAN}

Salah satu patokan dalam berinvestasi salah satunya yaitu kemudahan memperoleh informasi mengenai perkembangan harga saham di bursa efek. Informasi yang diperoleh merupakan hal yang dibutuhkan investor yang hendak melakukan investasi, beberapa informasi dapat dijadikan sebagai acuan sebelum melakukan transaksi berinvestasi pada pasar modal diantaranya inflasi, suku bunga, nilai tukar, fluktuasi harga, volume perdagangan, informasi penting terhadap emiten dan lain-lain.

Instrumen investasi yang ada di bursa efek Salah satunya adalah saham. Saham merupakan surat berharga yang menjadi bukti kepemilikan seseorang atas suatu perusahaan. Harga saham terutama saham sektor properti dan real estate beberapa tahun belakangan mengalami naik turunnya harga. Naik turunnya harga diakibatkan karena faktor makro ekonomi yaitu inflasi dan suku bunga yang sering mengalami fluktuasi. Hal ini yang mempengaruhi pergerakan harga saham (finance.detik.com).

Inflasi merupakan suatu proses meningkatnya harga-harga secara umum dan terus-menerus (continue). Inflasi yang terjadi di indoesia tidak stabil sejak 2012 hingga 2014 karena mengalami fluktuasi selama 3 tahun tersebut, masing-masing nilai inflasi yang tercatat di badan pusat statistik (BPS) yaitu $4,3 \%, 8,38 \%$ dan $8,36 \%$. Besar kecilnya tingkat inflasi tergantung dari besar kecilnya permintaan dan penawaran uang.

Teori permintaan uang berkaitan dengan faktor-faktor yang 
menyebabkan timbulnya permintaan uang, sedangkan teori penawaran uang berkaitan dengan jumlah uang yang tersedia, dan upaya dalam mengendalikannya agar tidak menimbulkan inflasi atau deflasi. Kekuatan permintaan dan penawaran uang di pasar finansial akan membentuk suku bunga.

Suku bunga merupakan Persentase dari pokok utang yang dibayarkan sebagai imbal jasa (bunga) atas peminjaman uang dalam suatu periode tertentu. Suku bunga yang terjadi mengalami kenaikan dan penurunan pada tahun 2012-2014 dengan tingkat suku bunga masing masing 5,77\%, 6,60\% dan 7,53\%. Perubahan tersebut dapat mempengaruhi harga saham perusahaan yang terdaftar di bursa efek indonesia.

Nilai tukar merupakan harga mata uang rupiah terhadap mata uang asing. Nilai tukar merupakan salah satu harga yang terpenting di dalam perekonomian, nila tukar pada tahun 2012 -2014 mengalami fluktuasi, masing-masing nilainya yaitu Rp9.380,39, Rp10.451,37 dan Rp.11.878,67. Fluktuasi yang terjadi dapat menyebabkan perubahan nilai investasi pada suatu perusahaan (www.bi.go.id).

Terdapat sembilan indeks sektoral pada Bursa Efek Indonesia (BEI), salah satu sektor tersebut adalah sektor properti dan real estate. Sektor properti dan real estate adalah salah satu sektor yang dapat menggambarkan keadaan terutama perekonomian suatu negara apakah dalam keadaan terpuruk atau dalam keadaan membangun, dikatakan demikian karena sektor properti dan real estate merupakan sektor utama dalam menciptakan kesejahteraan masyarakat.

Bisnis properti dan real estate Indonesia dapat dikatakan mengalami peningkatan, hal tersebut dapat dilihat dengan bertambahnya jumlah investor yang berinvestasi pada bisnis tersebut. Pertumbuhan sektor properti dan real estate di tandai dengan kenaikan harga tanah dan bangunan yang lebih tinggi dari nilai laju inflasi setiap tahunnya, hal ini yang menyebabkan banyak investor tertarik menanamkan modal pada sektor tersebut. Sektor properti dan real eestate termasuk dalam golongan aset yang memiliki nilai investasi tinggi dan dinilai cukup aman dan stabil.

Harga properti dan real estate (khususnya rumah) pada tahun 2010 -2014 mengalami kenaikan 10\%-20\%, dimana kenaikan harga tersebut dipengaruhi oleh salah satu faktor makro ekonomi yaitu inflasi. Kondisi perekonomian yang semakin pesat dan persaingan yang terjadi semakin gencar dalam pasar global merupakan suatu tantangan dan peluang bagi perusahaan dalam memperoleh modal untuk melakukan perluasan usaha, sehingga meningkatkkan keuntungan agar investor semakin tertarik berinvestasi pada perusahaan tersebut. Pasar modal perusahaan sektor properti dan real estate di Indonesia saat ini berkembang dengan cepat.

Berita ini ditandai dengan banyaknya perusahaan properti dan real estate yang go public di Indonesia (www.idx.com). Fenomena tersebut mengakibatkan harga saham properti dan real estate menjadi 
perhatian khusus investor karena harga saham sektor properti dan real estate tidak berada pada kondisi yang stabil pada tahun-tahun terakhir ini. Harga saham sektor properti dan real estate pada tahun 2012-2014 yaitu masing-masing Rp291,0558, Rp. 420,422 dan Rp. 444,0725 (www.idx.co.id), sehingga dapat dikatakan terjadi naik turun (fluktuasi) harga saham perusahaan sektor properti dan real estate pada tahun 2012 hingga 2014.

Fenomena naik, turunnya harga saham sektor properti dan real estate mengakibatkan investor cendrung melakukan pertimbangan setelah menganalisis harga saham yang nantinya di jadikan acuan dalam mengambil keputusan investasi pada saham. Selain fluktuasi harga, fenomena lain yang muncul yaitu tidak konsistennya hasil penelitian satu dengan hasil penelitian lainnya, diantaranya hasil penelitian yang dilakukan oleh Kustanto (2011) menerangkan bahwa inflasi, suku bunga, nilai tukar rupiah mempunyai pengaruh yang signifikan terhadap harga saham.

Penelitian yang sama namun hasil yang berbeda juga dilakukan oleh peneliti lainnya, dimana penelitian yang dilakukan oleh Permana (2012) menyatakan bahwa inflasi, suku bunga, tidak mempunyai pengaruh yang signifikan terhadap harga saham. Penelitan yang dilakukan oleh kewal (2012) mengatakan bahwa kurs rupiah berpengaruh negatif terhadap harga saham. Berdasarkan latar belakang penelitian dengan judul "Pengaruh inflasi, suku bunga dan nilai tukar rupiah terhadap harga saham perusahaan sektor properti dan real estate yang tercatat di Bursa Efek Indonesia" masih pantas untuk diteliti dengan alasan-alasan yang telah dijlaskan oleh peneliti pada latar belakang masalah diatas.

Berdasarkan permasalahan yang ada pada uraian latar belakang diatas, maka rumusan masalah dalam penelitian adalah :

Apakah inflasi, suku bunga dan nilai tukar rupiah berpengaruh secara simultan dan secara parsial terhadap harga saham sektor properti dan real estate yang tercatat di Bursa Efek Indonesia. Variabel mana yang paling berpengaruh terhadap harga saham sektor properti dan real estate yang tercatat di Bursa Efek Indonesia.

Pada penlitian ini diperlukan adanya batasan penelitian, hal ini dilakukan untuk menghindari agar penelitian tidak keluar dari pokok pembahasan. Adapun batasan penelitian sebagai berikut :

Perusahaan yang menjadi objek penelitian yaitu perusahaan sektor properti dan real estate yang sahamnya tercatat di BEI (Bursa Efek Indonesia).Data yang digunakan adalah data harga penutupan saham sektor properti dan real estate setiap bulan selama periode Januari 2012 hingga Desember 2014. Nilai tukar yang dijadikan acuan pada penelitian ini yaitu nilai tukar rupiah atas dollar dengan acuan kurs tengah setiap bulan selama periode Januari 2012 hingga Desember 2014. Suku bunga yang digunakan yaitu suku bunga $B I$ Rate setiap bulan selama periode Januari 2012 hingga Desember 2014.

Berdasarkan penjabaran rumusan masalah yang ada maka tujuan dari penelitian yaitu :

Untuk menguji pengaruh inflasi, suku bunga BI rate, dan nilai 
tukar rupiah terhadap harga saham sektor properti dan real estate yang tercatat di Bursa Efek Indonesia berpengaruh secara simultan dan secara parsial. Untuk mengujii diantara variabel inflasi, suku bunga dan nilai tukar rupiah mana yang paling berpengaruh terhadap harga saham sektor properti dan real estate yang tercatat di Bursa Efek Indonesia.

\section{TINJAUAN PUSTAKA}

Investasi yaitu penanaman modal atau penanaman uang dalam proses produksi dengan membeli gedung-gedung, mesin-mesin, bahanbahan cadangan, penyelenggaraan uang kas serta perkembangannya, dalam hal ini cadangan modal barang diperbesar selama tidak ada modal barang yang harus diganti. Hakikat investasi dalam definisi ini adalah penanaman modal yang dipergunakan untuk proses produksi.

Pasar modal adalah tempat berbagai pihak, khususnya perusahaan menjual saham (stock) dan obligasi (bond), dengan tujuan dari hasil penjualan tersebut nantinya akan dipergunakan sebagai tambahan dana atau memperkuat modal perusahaan (Irham Fahmi 2012:58).

\section{Menurut}

Jogiyanto

(2010:143) harga saham adalah harga yang terjadi di pasar bursa pada saat tertentu yang ditentukan oleh pelaku pasar dan ditentukan oleh permintaan dan penawaran saham yang bersang kutan di pasar modal.

Inflasi merupakan suatu kejadian yang menggambarkan situasi dan kondisi dimana harga barang mengalami kenaikan dan nilai mata uang mengalami pelemahan. Jika ini terjadi terus menerus maka akan mengakibatkan pemburukan kondisi ekonomi secara menyeluruh serta mengguncang tatanan stabilitas politik suatu negara (irham fahmi2012:67).

$\mathrm{BI}$ rate adalah suku bunga kebijakan yang mencerminkan sikap atau stance kebijakan moneter yang ditetapkan oleh Bank Indonesia dan diumumkan kepada publik. BI rate diumumkan oleh dewan gubernur Bank Indonesia setiap rapat dewan gubernur bulanan dan di implementasikan pada operasi moneter yang dilakukan Bank Indonesia melalui pengelolaan likuiditas (liquidity management) di pasar uang untuk mencapai sasaran operasional kebijakan moneter.

Menurut Peraturan Mentri Keuangan No 114/PMK. 04/2007 Pasal 1 yang dimaksud dengan nilai tukar adalah "Harga mata uang rupiah terhadap mata uang asing" (www.sjdih.kemenkeu.go.id). Kurs terdapat juga risiko nilai tukar yang artinya adalah risiko yang disebabkan oleh perubahan nilai investasi terhadap nilai tukar mata uang atau disebut juga dengan risiko nilai tukar atau risiko mata uang.

Hubungan antara Inflasi, Suku Bunga Bi Rate, dan Nilai tukar rupiah dengan harga saham Inflasi berhubungan dengan harga saham. Jika inflasi semakin tinggi menyebabkan terjadinya ketidak seimbangan di pasar modal, sehingga menyebabkan penurunan pada pertumbuhan investasi. Inflasi yang berlebihan dapat merugikan perekonomian secara keseluruhan, yaitu dapat membuat banyak perusahaan mengalami kebangkrutan (Irham Fahmi 2012:80).

Dalam penelitian ini menjelaskan pengaruh antara dua 
variabel yaitu variabel independen (X) dan variabel dependen (Y). Pengaruh yang dimaksudkan dalam penelitian yaitu pengaruh secara simultan dan parsial serta diantara variabel independen $(\mathrm{X} 1, \mathrm{X} 2, \mathrm{X} 3)$ manakah variabel yang paling memiliki pengaruh terhadap variabel dependen (Y). Secara sederhana kerangka pemikiran dalam penelitian ini yaitu seperti yang terlihat pada gambar 2.1 di bawah ini :

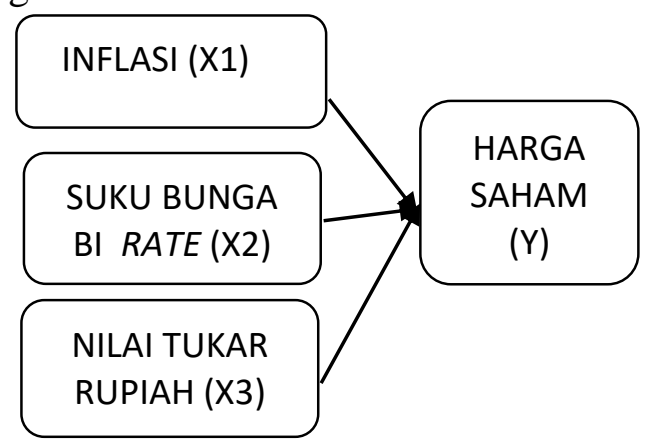

Gambar 1. Kerangka pikir

\section{METODE PENELITIAN}

Jenis penelitian yang digunakan dalam penelitian adalah jenis penelitian eksplanatori atau eksplanatif. Penelitian eksplanatori atau eksplanatif bertujuan untuk menjelaskan hubungan/pengaruh antara dua atau lebih gejala atau variabel.

Variabel Dependen yang digunakan dalam penelitian ini adalah variabel Harga saham, Merupakan harga saham penutupan yang berlaku pada periode penelitian dan diukur satuan rupiah, serta diberi simbol Y.

Variabel Independen yang digunakan dalam penelitian adalah Inflasi, Merupakan inflasi yang terjadi pada periode penelitian dan diukur dengan satuan persen, serta diberi simbol X1. Suku bunga BI rate Merupakan suku bunga yang berlaku pada periode penelitian diukur dengan satuan satuan persen serta diberi simbol X2. Nilai tukar rupiah, Merupakan nilai tukar nilai tukar dollar terhadap mata uang rupiah pada periode penelitian, diukur dengan satuan $\mathrm{Rp}$ (rupiah), serta diberi simbol X3. Populasi yang digunakan dalam penelitian ini adalah Populasi dalam penelitian ini adalah seluruh perusahaan property dan real estate yang terdaftar di BEI (Bursa Efek Indonesia) yang telah melakukan IPO (Initial Public Offering) atau perusahaan yang melakukan penawaran saham perdana.

Penelitian ini menggunakan teknik pengambilan sampel dengan metode nonprobability sampling dengan teknik purposive Sampling. Purposive Sampling adalah teknik penentuan sampel dengan pertimbangan-pertimbangan tertentu (Sugiyono, 2012:96).

Jenis data yang digunakan dalam penelitian ini menggunakan data kuantitatif. Sumber data yang digunakan dalam penelitian ini adalah data sekunder. Data sekunder diperoleh dari data sekunder diperoleh dari laporan tahunan Bank Indonesia (BI) pada situs (http://www.bi.go.id) yang secara lengkap mengenai inflasi, suku bunga, nilai tukar rupiah, dan harga saham pada situs (http://www.idx.co.id) dan

\section{HASIL PENELITIAN DAN PEMBAHASAN}

Berdasarkan kriteria dari pengambilan sampel maka diperoleh 30 perusahaan sektor properti dan real estate yang tercatat di Bursa Efek Indonesia. Hasil analisis data dalam penelitian ini adalah : 
Tabel 1. Uji statistik deskriptif

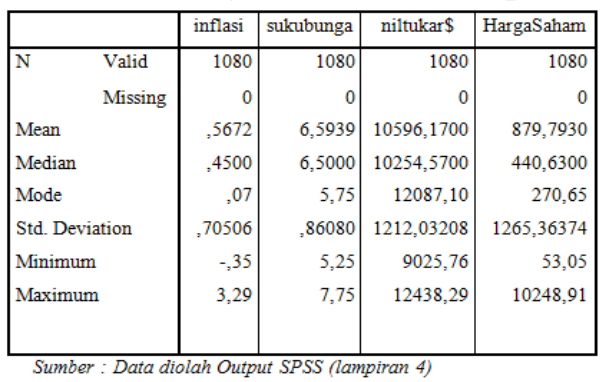

Nilai minimum x1 sebesar 0,35, menunjukkan bahwa di Indonesia terjadi penurunan harga secara umum dan kenaikan nilai mata uang (deflasi). Nilai maksimum sebesar 3,29, menunjukkan bahwa inflasi tinggi yang terjadi di Indonesia kemungkinan disebabkan oleh inflasi permintaan (demand pull inflation) dan inflasi desakan biaya (cost push inflation) (wikipedia.com). Rata-rata inflasi sebesar 0,57 dan standar deviasi sebesar 0,705 (0,71).

Nilai minimum $\mathrm{x} 2$ sebesar 5,75 , hal ini menunjukkan tingkat suku bunga selama periode tersebut rendah. Nilai maksimum sebesar 7,75 , menunjukkan bahwa pada bulan Desember 2014 suku bunga di Indonesia meningkat. Nilai rata-rata suku bunga sebesar 6,59 dan standar deviasi sebesar 0,86 .

Nilai minimum $\mathrm{x} 3$ sebesar Rp9025,76, menunjukkan bahwa nilai tukar rupiah menguat disebabkan oleh permintan dan penawara, kebijakan pemerintah dan mekanisme pasar. Nilai maksimum yaitu Rp12438,29, menunjukkan bahwa nilai rupiah melemah terhadap nilai mata uang dollar, melemahnya nilai tukar di indonesia dapat disebabkan oleh mekanisme pasar dan kebijakan pemerintah. Nilai ratarata sebesar Rp10596,17 dan standar deviasi sebesar Rp1212,032.
Nilai minimum $\mathrm{Y}$ sebesar 53,05 terjadi pada pada perusahaan dengan kode emiten BIPP (Bhuawanatala Indah Permai, Tbk), kondisi ini dilatar belakangi oleh kurang efektifnya pengelolaan modal saham yang telah diinvestasikan oleh pemegang saham.

Uji asumsi klasik yang digunakan pada penelitian ini yaitu uji normalitas, uji multikoliniearitas, uji heteroskedastisitas dan uji normalitas. Berikut hasil perhitungan masingmasing uji :

Hasil dari uji normalitas dengan menggunakan P-P Plot of Regression Standarization Residual semua data variabel inflasi, suku bunga, dan nilai tukar rupiah telah berdistribusi dengan normal karena memberikan hasil bahwa data menyebar di sekitar garis diagonal dan mengikuti arah garis, dapat di jelaskan bahwa uji normalitas terpenuhi.

Hasil dari uji multikolinearitas, menyatakan masing masing nilai VIF variabel independen inflasi (x1) yaitu sebesar 1,066 variabel suku bunga (x2) dengan nilai VIF 4,529 dan dan nilai tukar rupiah (x3) dengan VIF sebesar 0,215, dan nilai tolerance dibawah 10. Aturan VIF yaitu apabila nilai $\mathrm{VIF} \leq 10$ dan toleransi $\geq 0,10$, maka dapat disimpulkan bahwa tidak terjadi gejala multikolinieritas.

Hasil uji glejser menunjukkan dari seluruh variabel tidak menunjukkan adanya nilai yang signifikan pada tingkat 0,05 karena pada masing-masing variabel inflasi (x1) sebesar 0,704>0,05, variabel suku bunga (x2) signifikan sebesar $0,390>0,05$ dan variabel nilai tukar rupiah (x3) yaitu sebesar 0,334>0,05. Penelitian ini menunjukkan bahwa tidak ada gejala heteroskedastisitas. 
Hasil dari uji autokorelasi menunjukan bahwa tidak terdapat autokorelasi baik positif maupun negatif dilihat dari hasil Durbin Watson menunjukan angka 0,071 yang artinya hasil tersebut berada di antara angka yang termasuk dalam kategori tidak ada autokorelasi yaitu 2 sampai +2 .

Uji asumsi klasik yang digunakan dalam penelitian yaitu $\mathrm{Y}=-101,983+28,361(\mathrm{x} 1)-183,898$ $(\mathrm{x} 2)+0,206(\mathrm{x} 3)$

$\mathrm{a}=-101,983$, artinya jika semua variabel bebas bernilai 0 atau tidak mengalami perubahan, maka nilai variabel terikat sebesar -101,983.

$\mathrm{b}_{1}=28,361$, artinya jika variabel bebas lainnya bernilai tetap dan variabel inflasi (x1) mengalami kenaikan $1 \%$ maka harga saham akan mengalami kenaikan sebesar Rp28,361.

$\mathrm{b}_{2}=-183,898$, artinya apabila variabel bebas lainnya bernilai tetap dan variabel suku bunga (x2) mengalami kenaikan $1 \%$ maka harga saham akan mengalami penurunan harga sebesar Rp183,898.

$\mathrm{b}_{3}=0,206$, artinya apabila variabel bebas lainnya bernilai tetap dan variabel nilai tukar rupiah (x3) mengalami kenaikan kenaikan $1 \%$ maka harga saham akan mengalami kenaikan sebesar Rp0,206.

Koefisien determinasi $\left(R^{2}\right)$ menunjukkan bahwa angka nilai koefisien determinas (adjusted $R$ square) sebesar 0,012 atau 1,2\%. Hasil tersebut menunjukkan bahwa sebesar $1,2 \%$ variabel dependen dapat dijelaskan oleh variabel independen yaitu inflasi, suku bunga, dan nilai tukar rupiah. Sedangkan $98,8 \%$ dipengaruhi oleh variabel lain diluar variabel pada
penelitian.Menunjukkan bahwa kemampuan variabel independen sangat terbatas dalam menjelaskan variabel dependen.

Pengujian Hipotesis 1 dalam penelitian ini menggunakan uji $\mathrm{F}$ dan uji t. Hasil uji F hitung sebesar 4,377 dan F tabel (df1=3 dan df2=1077) sebesar 2,61317, hal ini menunjukkan bahwa $\mathrm{F}$ hitung $>$ dari $\mathrm{F}$ tabel dengan signifikan 0,002<0,05. Hasil tersebut dapat disimpulkan bahwa secara bersama-sama variabel independen berpengaruh terhadap variabel dependen.

Nilai t hitung sebesar 0,819 sedangkan nilai t tabel yaitu 1,64627 (level $\alpha=0,05$ dan $\mathrm{df}=1076$ ) dengan signifikansi 0,413>0,05. Berdasarkan hasil tersebut dapat disimpulkan bahwa nilai $\mathrm{t}$ hitung $<\mathrm{t}$ tabel dan signifikansi $>0,05$, hasil pengujian tersebut menunjukkan bahwa variabel $\mathrm{x} 1$ (inflasi) tidak memiliki pengaruh terhadap variabel dependen (harga saham).

Nilai t hitung sebesar $-2,788$ sedangkan nilai t tabel yaitu $-1,9617$ (level $\alpha=0,05 \mathrm{dan} \mathrm{df}=1076$ ) dengan signifikansi $0,005<0,05$. Berdasarkan hasil tersebut dapat disimpulkan bahwa nilai -t hitung < t tabel dan signifikansi $<0,05$, hasil pengujian tersebut menunjukkan bahwa variabel x2 (suku bunga) memiliki pengaruh negatif signifikan terhadap variabel dependen (harga saham).

Nilai tukar rupiah yaitu sebesar 2,180 dan nilai $t$ hitung sebesar 3,472 sedangkan nilai t tabel yaitu 1,64627 (level $\alpha=0,05$ dan $d f=$ 1076) dengan signifikansi $0,001<$ 0,05 . Berdasarkan hasil tersebut dapat disimpulkan bahwa nilai $\mathrm{t}$ hitung $>\mathrm{t}$ tabel dan signifikansi $>0,05$, hasil 
pengujian tersebut menunjukkan bahwa variabel x3 (Nilai tukar rupiah) mempunyai pengaruh positif dan signifikan terhadap variabel dependen (harga saham).

$$
\text { Pengujian Hipotesis 2, }
$$

Hipotesis kedua pada penelitian ini yaitu menjelaskan variabel independen yang paling memiliki pengaruh terhadap varibel dependen, hasil penelitian menunjukkan bahwa variabel yang paling berpengaruh yaitu inflasi dengan $t$ hitung sebesar 3,472 .

Pembahasan hasil penelitian ini menjelaskan pengaruh variabel inflasi, suku bunga dan nilai tukar rupiah terhadap harga saham.

Pengaruh inflasi terhadap harga saham, variabel inflasi (x1) tidak memiliki pengaruh terhadap variabel dependen (harga saham). Hasil tersebut menunjukkan inflasi yang terjadi sama sekali tidak mempengaruhi perubahan harga saham.

Tandelilin

mengatakan bahwa peningkatan inflasi secara relatif merupakan sinyal negatif bagi pemodal di pasar modal. Hal ini berarti jika inflasi naik maka akan menurunkan harga saham dan jika inflasi turun akan meningkatkan harga saham.

Hasil uji parsial pada penelitian ini konsisten dengan penelitian yang dilakukan oleh suryanto (2012) bahwa inflasi tidak mempunyai pengaruh yang signifikan terhadap haga saham sektor properti dan real estate, dan menolak hasil penelitian yang dilakukan oleh Sugeng raharjo (2010) yang mengatakan bahwa inflasi mempunyai pengaruh yang positif terhadap harga saham.
Berdasarkan hasil pengujian uji statistik t (parsial) menunjukkan bahwa variabel suku bunga (x2) memiliki pengaruh negatif signifikan terhadap variabel (dependen harga saham). Hasil pengujian menunjukkan bahwa adanya pengaruh antara suku bunga dengan harga saham.

Suku bunga memiliki arti terbalik (cateris paribus) jika suku bunga meningkat, maka harga saham akan turun, hal ini disebabkan karena keputusan investor yang menjual saham dan beralih kepada investasi lain yang lebih menguntungkan seperti deposito. Sebaliknya, jika suku bunga turun, maka harga saham akan naik (Tandelilin, 2010:103). Suku bunga turun menyebabkan harga saham mengalami kenaikan.

Hasil uji parsial (t) pada penelitian ini konsisten dengan penelitian yang dilakukan oleh suryanto (2012) bahwa suku bunga mempunyai pengaruh negatif signifikan terhadap haga saham sektor properti dan real estate, dan menolak hasil penelitian yang dilakukan oleh Sugeng raharjo (2010) yang mengatakan bahwa suku bunga tidak mempunyai pengaruh yang positif terhadap harga saham.

Nilai tukar rupiah (x3) mempunyai pengaruh positif signifikan terhadap variabel dependen (harga saham). Data-data transaksi perdagangan di bursa efek, menunjukkan adanya pengaruh yang kuat antara pergerakan fluktuasi nilai mata uang dengan fluktuasi hargaharga saham yang diperdagangkan di bursa (simatupang, 2010:76).

Melemahnya (menurunnya) nilai tukar rupiah terhadap nilai mata uang asing (dollar Amerika) 
berdampak negatif terhadap pasar ekuitas, sehingga menyebabkan pasar modal tidak diminati oleh investor, menyebabkan investor berali kepada pasar uang karena memiliki keuntungan lebih besar.

Hasil uji parsial (t) pada penelitian ini berbeda dengan penelitian yang dilakukan oleh suryanto (2012) bahwa nilai tukar rupiah mempunyai pengaruh yang dan signifikan terhadap haga saham sektor properti dan real estate, dan berbeda hasil penelitian yang dilakukan oleh Sugeng raharjo (2010) yang mengatakan bahwa nilai tukar rupiah tidak mempunyai pengaruh yang positif terhadap harga saham.

Variabel independen yang mampu menjelaskan variabel yang paling berpengaruh yaitu variabel $\mathrm{x} 3$ dimana hasil uji $\mathrm{t}$ statistiknya melebihi hasil t hitung dengan hasil yang positif, hal ini dapat disimpulkan bahwa nilai tukar memiliki peranan sangat penting terhadap harga saham pada perusahaan sektor properti dan real estate yang tercatat pada Bursa Efek Indonesia pada tahun 2012-2014. Adanya pengaruh terbesar bahwa nilai tukar rupiah mengalami penguatan pada tahun 2012-2014 dan keadaan perekonomian indonesia dalam keadaan baik dan stabil. Kondisi perekonomian indonesia yang stabil akan mendorong para investor untuk melakukan investasi pada pasar modal.

\section{SIMPULAN}

Berdasarkan hasil pengujian dapat disimpulkan bahwa secara bersama-sama Inflasi, Suku bunga, dan nilai tukar rupiah berpengaruh terhadap Harga saham. hasil pengujian menjelaskan bahwa inflasi tidak bepengaruh signifikan terhadap harga saham sektor properti dan real estate, Suku bunga berpengaruh negatif dan signifikan terhadap harga saham sektor properti dan real estate dan nilai tukar rupiah berpengaruh positif dan signifikan terhadap harga saham sektor properti dan real estate. Hasil analisis regresi menunjukkan bahwa variabel independen yang paling berpengaruh terhadap variabel dependen saham sektor properti dan real estate. yaitu variabel nilai tukar rupiah atas dollar Amerika.

Bagi emiten, para emiten perlu berhati-hati dalam mengambil kebijakan dalam menjual sahamnya, selain melihat faktor fundamental dan faktor internal, perusahaan juga penting melihat faktor makro ekonomi seperti inflasi, suku bunga dan nilai tukar serta faktor lainnya, dalam hal ini para emiten harus mempertimbangkan suku bunga dan nilai tukar rupiah terhadap dollar dalam mengambil keputusan membeli atau menjual saham yang dimiliki.

Bagi investor, yang ingin menginvestasikan sebagian dananya di pasar modal sebaiknya mempertimbangkan dan melakukan analisis faktor yang dapat mempengaruhi harga saham suatu perusahaan, seperti inflasi suku bunga dan nilai tukar rupiah. Hasil penelitian menunjukkan suku bunga dan nilai tukar rupiah dapat mempengaruhi harga saham dan dapat dijadikan acuan dalam pengambilan keputusan apakah membeli atau tidak saham tersebut. 


\section{DAFTAR PUSTAKA}

A. Karim, Adiwarman. 2011. Ekonomi Makro Islam. Edisi kedua. PT. Raja Grafindo Persada. Jakarta

Alwi, Iskandar Z, 2008. Pasar Modal Teori dan Aplikasi, Yayasan PancurSiwah, Jakarta.

Darmadji, Tjiptono, dan Fakhruddin. 2011. Pasar Modal Di Indonesia: Pendekatan Tanya Jawab. Edisi Ketiga, Salemba Empat, Jakarta.

Fahmi, Irham. 2012. Pengantar pasar modal edisi pertama. Bandung : Alfabeta.

Ghozali, imam. 2011. Aplikasi Analisis Multivariate dengan program IBM SPSS19. Edisi 5. Badan Penerbit Universitas Diponegoro,Semarang.

Jogiyanto, Hartono.2010. Teori Portofolio dan analisis investasi. Edisi ketuju. Yogyakarta, BPFE.

Madura, jeff 2009. Intruduction to 3E Business. Canada: Mangasa Simatupang. (2010). Pengetahuan Praktis Investasi Saham dan Dana Reksa. Mitra Wacana Media, Jakarta.

Rahardja, Prathama, Mandala Manurung. 2012. Pengantar Ilmu Ekonomi (Mikroekonomi dana Makroekonomi). Edisi ke-3 Fakultas Ekonomi Universitas Indonesia, Jakarta.

Samsul Mohammad. 2006. Pasar Modal dan manajemen Portofolio. Erlangga, Surabaya

Siamat, dahlan. 2005 Manajemen lembaga keuangan; Kebijakan Moneter dan perbankan. (Edisi kelima) Lembaga penerbit Fakultas Ekonomi Universitas Indonesia, Jakarta.
Sihaloho, Lira. 2013. Pengaruh Inflasi, Suku bunga dan Book value (BV) Terhadap Harga Saham Perusahaan LQ45 yang terdaftar di Bursa Efek Indonesia (BEI pada Tahun 2008- 2011). Jurnal manajemen universitas Negeri Semarang.

Santoso, Singgih. 2002. Riset Pemasaran Konsep dan Aplikasi dengan SPSS. Jakarta: PT Gramedia.

Sugiyono. 2012. Metode Penelitian Kuantitatif kualitatif dan $R \& D$.

Cetakan Ke-20. Penerbit Alfabeta, Bandung.

Sugeng Raharjo. 2010. Pengaruh inflasi, Nilai kurs rupiah dan Tingkat suku bunga terhadap harga saham di Bursa Efek Indonesia. Jurnal STIE “AUB”Surakarta.

Suramaya Suci Kewal. 2012. Pengaruh inflasi, suku bunga, kurs, dan pertumbuhan PDB terhadan Indeks Harga saham Gabungan. Jurnal Sekolah Tinggi Ilmu Ekonomi Musi Palembang, Indonesia.

Suryanto. 2012. Pengaaruh inflasi, Suku bunga BI Rate dan Nilai Tukar Rupiah Terhadap Harga Saham Perusahaan Sektor Properti dan Real Estate di Bursa Efek Indonesia. Jurnal Administrasi Bisnis Universitas Padjadjaran

Tandelilin, Eduardus, 2010. Portofolio dan Investasi Teori dan Aplikasi, Edisi Pertama. Kanisius, Yogyakarta.

Umi Mardiyanti, Ayi Rosalina. 2013. Analisis pengaruh nilai tukar,tingkat suku bunga dan inflasi terhadap indeks harga saham. Studi kasus pada 
perusahaan Properti yang terdaftar di Bursa Efek Indonesia.

Jurnal Universitas Negeri Jakarta.

Weston, J. F dan E. F. Brigham. 2001.Fundamental of Finincial Statement:Dasar-

DasarManajemen Keuangan.

Terjemahan Alfonsu Sirait. Jakarta. Erlangga.

Zalmi Zubir, (2011). Manajemen Portofolio: Penerapannya dalam investasi saham. Salemba Empat, Jakarta.

http://lusiangraini.blogspot.co.id/201

1/ 12/populasi-dan-sampel.html diakses tanggal 23 November 2015.

https://titaviolet.wordpress.com/2009 /07/17/pengujian-hipotesis distribusi-uji-t-dan-f-pada-modelregresi-berganda/ diakses 20 januari 2016.

http://www.asikbelajar.com/2015/10/ pengertian-hipotesis-menurutpara-ahli.html diakses tanggal 23 November 2015.

http://www.bi.go.id/en/Default.aspx diakses tanggal 26 November 2015. http://www.idx.co.id/idid/beranda/inf ormasi/bagiinvestor/penganta rpasarmodal. aspx diakses tanggal 20 November 2015.

http://www.pengertianahli.com/2013/ 11 /pengertian-data-dan-jenisdata.html diakses tanggal 23 November 2015.

http://www.sahamok.com/emiten/sek tor-property-real-estate/subsektor-property- realestate diaksestanggal 23 November 2015.

http://www.sjdih.kemenkeu.go.id/full Text/2007/114 2007per.HT MLdiakses tanggal 23 November 2015.

https://id.wikipedia.org/wiki/Inflasi diakses tanggal 23 November 2015.

https://id.wikipedia.org/wiki/Pasar_ modal diakses tanggal 25 November 2015.

https://id.wikipedia.org/wiki/Peneliti an_eksplanatori diakses tanggal 23 November. 